\title{
The Dynamism of Teachers' Identity: The Case of Iranian EFL Teachers
}

\author{
Afsaneh Ghanizadeh, Shima Abedi Ostad \\ Imam Reza International University, Mashhad, Iran
}

\begin{abstract}
Recent conceptualizations of professional identity as an ongoing process of interpretation and re-interpretation of experiences demonstrate that it is dynamic and subject to an ongoing learning process. In effect, identity is essentially viewed as fluid, dynamic, recursive, and discursive process in which statements about actions are translated into statements about states, and vice versa. Having these standpoints in mind, the present paper aims at depicting the profile of English as a foreign language (EFL) teachers' professional identity. The second purpose of this study is to examine the relationships among the components of teachers' professional identity as measured by Kao and Lin's (2015) model comprising six latent factors of teachers' professional identity: self-expectation (SE), teachers' duties (TD), external influential factors (EF), pedagogy (PE), instructional skills and knowledge (SK), and teachers' citizenship behavior (CB). This study also sought to scrutinize the dynamics of teachers' identity in accordance with their teaching experience, gender, and educational level. For these purposes, 110 EFL teachers were chosen from different language institutes in Mashhad, a city in northeastern Iran. The results indicated that SE received the highest value and $\mathrm{EF}$ obtained the lowest mean score in our sample. The highest correlation was observed between SK and PE, followed by the relationship between TD and PE. The results indicated that there were significant correlations between teachers' teaching experience and all the teachers' identity components. It was also found that there were statistically significant differences between male and females in four components of identity as follows: TD, PE, SK, and CB. The results showed that there were variations in teacher identity with regards to their educational level.
\end{abstract}

Keywords: teachers' professional identity, EFL teachers, teaching experience, educational level, gender

\section{Introduction}

In the constructivist view, teachers are not unreceptive experts, who chiefly practice others' hypotheses; teacher education, nevertheless, views teachers as intelligent specialists who can conjecture about their practices and implement their own speculations (Wallace, 1995; Griffiths, 2000; Kumaravadivelu, 2003). This new comprehension incited the enthusiasm among specialists in teacher related issues, for example, teacher cognizance, teacher convictions (e.g., Freeman, 1996, 1998; Freeman \& Johnson, 1998; Woods, 1996), and, particularly in the late decade, teacher professional identity (e.g., Nguyen, 2008; Singh \& Richards, 2006; Tsui, 2007). According to Enyedy, Goldberg, and Welsh (2006), "Identity is a complex construct, yet extremely important if we wish to understand the practice of teaching as a profession" (p. 112). 
Usually, the utilization of the term "professional" aids distinguishing between professionals and non-professionals. Teacher professional identity is the means by which teachers characterize their professional parts (Lasky, 2005). This dynamic construct (Barrett, 2008; Varghese, Morgan, Johnston, \& Johnson, 2005) has been appeared to effectively affect teachers' improvement and execution. In the teaching context, professional identity relies upon three-pronged principle attributes: (1) skill in one's range of specialization; (2) moral integrity; and (3) expertise in didactical terms. Of course, other significant attributes include specialized knowledge, code of professional ethics, professional autonomy, organization and regulation, and public service provision (Carr, 2000).

Professional identity includes an individual's self-concept and identity that begin from deciphering and reinterpreting his or her professional experience. Since it is a social build coming out of communications among a few components, for example, individuals' subjective experience and basic self-examination, professional identity does not stay in a consistent condition (Ivanic, 1997; Pinar, 2012; Wenger, 1998). In a similar vein, Abednia (2012) contended that "identity is a highly dynamic construct which changes as a result of individuals' interaction with others in the environment" (p. 714).

In Lauriala and Kukkonen's (2005) perspective, identity and self-concept are the same. The term identity has been all the more usually utilized regarding teachers, and the term self-concept concerning students. They consider both identity and self-concept to be stable and dynamic in the meantime. Imperatively, identity and practice reflect each other. As Wenger (1998) contended, there is a critical relationship amongst identity and practice. Developing a practice requires the course of action of a gathering whose people can interface with each other and in this way perceive each diverse as individuals. Kerby's (1991) description of professional identity as an ongoing process of interpretation and re-interpretation of experiences demonstrates that it is dynamic and subject to an ongoing learning process.

Friesen and Besley (2013) recommended that the individuals who have a balanced feeling of individual identity will probably be prepared to start the way toward building a professional identity, which is a formative and social mental procedure. As to change of teachers' professional identity, in spite of the fact that teachers as professionals have slowly gotten to be subjected to outer measures and professional codes, their own particular office serves as an intense shield for developing their professional identity and reinforcing their dedication (Thomson \& Palermo, 2014).

Teachers' adequacy, professional advancement, and acknowledgment for change may likewise be influenced by their professional identity (Beijaard, Verloop, \& Vermunt, 2000; Masoumpanah \& Zarei, 2014). Guideline gets to be effectiveness situated, which undermines the identity of teachers and along these lines undermines their inspiration and adequacy. It is also believed that 'the formative years' experience and students' preferences in learning English were primary factors that influenced teachers' professional identity and their sense of subject competence and these formed influential factor in the interaction between professional identity and teachers' attitudes towards the notion of EIL" (Masoumpanah \& Zarei, 2014, p. 1106).

Kao and Lin (2015) reviewing the literature on the professional identity of teachers came up with two categories conceptualizing various aspects of teacher identity: (1) formation and development of teachers' professional identity and (2) identification of characteristics of teachers' professional identity (Rus, Tomşa, Rebega, \& Apostol, 2013). Professional identity of teachers encompasses internal and external factors such as, teachers' personal life experience, teachers' thinking about instruction, personal values and expectations for the 
future, and teachers' relationships with peers, work environment redesign, organizational structure, the implementation of teaching, education reform, school leadership, and professional development (Kao \& Liu, 2015).

In a number of studies, professional identity of teachers has been related to images of self while in others the emphasis was on teachers' roles. In an occupation where who one is as a person is so much interwoven with how one acts as a professional, both sides cannot be separated: "it seems unlikely that the core of the personal will not impact the core of the professional" (Loughran, 2006, p. 112).

Four features of professional identity stemming from the Beijaard, Meijer, and Verloop's (2004) works were studied. They determine that identity is an ongoing process, and therefore identity is dynamic rather than stable, a constantly evolving phenomenon. It involves both a person and a context: Within a context, teachers learn professional characteristics that are adopted by individuals in unique ways. Within a teacher's professional identity are sub-identities, which may be more or less central to the overall identity and must be balanced to avoid conflict across them. Professional identity comprises the notion of agency, or the active pursuit of professional development and learning in accordance with a teacher's goals. These authors point to the problematic nature of the various understandings of identity, in particular the connection between identity and self, and the unclear distinction between personal and professional identity. Indeed it appears that a clear definition of identity is not easily reached, but that there is general acknowledgement of its multi-faceted and dynamic nature.

Teacher professional identity then stands at the core of the teaching profession. It provides a framework for teachers to construct their own ideas of "how to be", "how to act", and "how to understand" their work and their place in society. Importantly, teacher identity is not something that is fixed nor is it imposed; rather it is negotiated through experience and the sense that is made of that experience (Sachs, 2005, p. 15). Luehmann (2007) contended becoming a good teacher includes significantly more than gaining another arrangement of information and abilities, and that this procedure could be better comprehended and upheld once scientists consider it building up another professional identity. Komba, Anangisye, and Katabaro (2013) claimed, the formation of teacher professional identity has largely been influenced by the level of training in pedagogy, academic training, and practical experience as an academician.

The current study utilizes a theoretical framework conceptualized by Kao and Lin (2015) which elucidates teachers' professional identity in six dimensions: self-expectation (SE), teachers' duties (TD), external influential factors (EF), pedagogy (PE), instructional skills and knowledge (SK), and teachers' citizenship behavior (CB). By SE we mean teachers' commitment to and evaluation of their job. TE is teachers' responsibilities toward students, curriculum content, and society. EF is defined as teachers' perceptions of social interactions and school policy. PE is students' behavioral education and relationships with students. SK is teachers' subject knowledge and approaches for delivering curriculum. CB is teachers' devotion of additional efforts in their work and profession.

\section{Purpose of the Study}

In a nutshell, the above literature on teachers' professional identity demonstrated that studies on this issue left out a space for doing a research on different dimensions of teachers' professional identity and other factors. To the researchers' best knowledge to date, notwithstanding a plethora of studies on teachers' identity, little research has been conducted to delve into EFL teachers' identity and the possible variations according to 
teachers' experience, gender, and educational level. To attain the goals of present research, the following research questions were posed and investigated in the present study:

(1) What is the profile of Iranian EFL teachers' professional identity?

(2) What is the relationship among the components of teachers' professional identity?

(3) Is there any significant relationship between EFL teachers' professional identity and teaching experience?

(4) Is there any significant relationship between EFL teachers' professional identity and their gender?

(5) Is there any significant relationship between EFL teachers' professional identity and their educational level?

\section{Methodology}

\section{Participants}

The sampling frame was limited to schools and English language institutes in Mashhad, a city in northeastern of Iran. In this study, 110 teachers (77 females, 33 males) were selected according to a convenience sampling from different schools and English language institutes. All participants were instructed to respond to 22 items on 5-point Likert scales ranging from 1 (strongly disagree) to 5 (strongly agree) and were asked not to write their names in order that their views would be confidential. The participation was entirely voluntary. They were required to indicate demographic information such as gender, age, major, years of English teaching experience, and place of teaching. The questionnaires were coded numerically.

Participants' age varied from 20 to 49 years old $(\mathrm{M}=28.21, \mathrm{SD}=5.97)$ with 1 to 22 years of English teaching experience $(\mathrm{M}=7.48, \mathrm{SD}=5.35)$, their degree varied from B.A. to Ph.D. of English Literature, English Translation, and English Teaching. The design of this study was correlational.

\section{Instrumentation}

To evaluate teachers' professional identity, a questionnaire was given to the participants. The questionnaire measured teachers' professional identity and was designed and validated by Kao and Liu (2015). It included 22 items with a textual format on 5-point Likert scales ranging from 1 (strongly disagree) to 5 (strongly agree). In this study the total reliability of the questionnaire, estimated via Cronbach's alpha, was .75. These items gauged six factors: Self-expectation (SE), Teachers' duties (TD), External influential factors (EF), Pedagogy (PE), Instructional skill and knowledge (SK), and Teachers' citizenship behavior (CB). Sample items for each component are as follows:

SE: Statements regarding my career by others are consistent with what I perceive myself.

TD: I believe that being responsible for students is one of my professional duties.

EF: Parents' attitudes influence my teaching.

PE: As a teacher, I always lead by example to teach students how to get along with others.

SK: I believe that teachers should be able to teach most students to understand the content of teaching material.

CB: I am willing to expend additional time to help students solve academic problems.

\section{Results}

Table 1 presents descriptive statistics of teachers' professional identity. Throughout this study, SE stands for self-expectation, TD stands for teachers' duties, EF for experience of failure, EF for external influential 
factors, PE for pedagogy, SK for instructional skills and knowledge, and CB for teachers' citizenship behavior. As the table indicates, $\mathrm{SE}$ receives the highest mean $(\mathrm{M}=16.42, \mathrm{SD}=4.14)$ and $\mathrm{EF}$ obtained the lowest mean score $(\mathrm{M}=10.39, \mathrm{SD}=2.23)$.

Table 1

Descriptive Statistics of Teachers' Professional Identity

\begin{tabular}{lllllll}
\hline & $\mathrm{N}$ & Minimum & Maximum & Possible Range & Mean & Std. Deviation \\
\hline SE & 110 & 5.00 & 24.00 & $5-25$ & 16.4273 & 4.14742 \\
TD & 110 & 4.00 & 15.00 & $3-15$ & 10.4909 & 2.61522 \\
EF & 110 & 5.00 & 15.00 & $3-15$ & 10.3909 & 2.23851 \\
PE & 110 & 8.00 & 20.00 & $4-20$ & 14.4027 & 3.11171 \\
SK & 110 & 7.00 & 20.00 & $4-20$ & 14.4727 & 3.96940 \\
CB & 110 & 4.00 & 15.00 & $3-15$ & 10.8455 & 2.54568 \\
Valid N (list wise) & 110 & & & & & \\
\hline
\end{tabular}

Notes. The reliability estimates of each variable computed via Cronbach's alpha were as follows: $\operatorname{SE}(\alpha=.72)$, TD $(\alpha=.70)$, EF $(\alpha=.68)$, PE $(\alpha=.61)$, SK $(\alpha=.63)$, and $\mathrm{CB}(\alpha=.65)$.

To see the interrelationships among identity components, multiple Pearson Product correlations were conducted. The results are displayed in Table 2 .

Table 2

The Correlation Coefficients Among Identity Components

\begin{tabular}{lllllll}
\hline & 1 & 2 & 3 & 4 & 5 & 6 \\
\hline $1 . \mathrm{SE}$ & 1.00 & & & & & \\
$2 . \mathrm{TD}$ & $.475^{* *}$ & 1.00 & & & & \\
$3 . \mathrm{EF}$ & $.319^{* *}$ & $.323^{* *}$ & 1.00 & & & \\
$4 . \mathrm{PE}$ & $.586^{* *}$ & $.630^{* *}$ & $.320^{* *}$ & 1.00 & 1.00 & .00 \\
$5 . \mathrm{SK}$ & $.587^{* *}$ & $.719^{* *}$ & $.397^{* *}$ & $.827^{* *}$ & $.603^{* *}$ & 1.00 \\
$6 . \mathrm{CB}$ & $.427^{* *}$ & $.517^{* *}$ & $.267^{* *}$ & $.559^{* *}$ & \\
\hline
\end{tabular}

Notes. **Correlation is significant at the level of 0.05 .

As the table indicates, the highest correlation is observed between SK (instructional skills and knowledge) and PE (pedagogy) $(r=0.827, p<0.05)$, followed by the relationship between TD (teachers' duties) and PE (pedagogy) $(\mathrm{r}=0.630, \mathrm{p}<0.05)$.

The nexus between teacher identity and years of teaching experience was examined via a correlation analysis. The results are presented in Table 3.

Table 3

The Correlation Coefficients Between Identity Components and Teaching Experience

\begin{tabular}{lllllll}
\hline & SE & TD & EF & PE & SK & CB \\
\hline Teaching Experience & $.415^{* *}$ & $.204^{* *}$ & $.26^{* *}$ & $.245^{* *}$ & $.245^{* *}$ & $.203^{* *}$ \\
\hline
\end{tabular}

Notes. **Correlation is significant at the level of 0.05 .

To determine the relationship between identity components and teaching experience, a Pearson product-moment correlation was run. The findings indicated that there are significant correlations between teachers' teaching experience and SE $(r=0.415, \mathrm{p}<.05)$, teachers' teaching experience and TD $(r=0.204, \mathrm{p}$ $<.05)$, teachers' teaching experience and EF $(\mathrm{r}=0.26, \mathrm{p}<.05)$, teachers' teaching experience and PE $(\mathrm{r}=$ 
$0.245, \mathrm{p}<.05)$, teachers' teaching experience and SK $(\mathrm{r}=0.245, \mathrm{p}<.05)$ and teachers' teaching experience and $\mathrm{CB}(\mathrm{r}=0.203, \mathrm{p}<.05)$.

To investigate gender-differences in each identity component, independent samples $t$-tests were run. Table 4 below summarizes the descriptive results of identity across male and female teachers. As the table shows, the mean scores of all identity components across the two groups are different: $\mathrm{SE}$ : male $(\mathrm{M}=15.60, \mathrm{SD}=3.69)$, female $(M=16.77, S D=4.30)$, $T D:$ male $(M=9.24, S D=2.16)$, female $(M=11.02, S D=2.62)$, $E F$ : male $(M$ $=9.84, \mathrm{SD}=1.90)$, female $(\mathrm{M}=10.62, \mathrm{SD}=2.33)$, PE: male $(\mathrm{M}=12.57, \mathrm{SD}=3.02)$, female $(\mathrm{M}=15.28, \mathrm{SD}$ = 2.79), $\mathrm{SK}:$ male $(\mathrm{M}=12.27, \mathrm{SD}=3.41)$, female $(\mathrm{M}=15.41, \mathrm{SD}=3.83)$, and $\mathrm{CB}:$ male $(\mathrm{M}=9.78, \mathrm{SD}=$ 2.60), female $(\mathrm{M}=11.29, \mathrm{SD}=2.39)$.

Table 4

Descriptive Statistics of Identity Across Male and Female Teachers

\begin{tabular}{llllll}
\hline & Gender & $\mathrm{N}$ & Mean & Std. Deviation & Std. Error Mean \\
\hline \multirow{2}{*}{$\mathrm{SE}$} & 1 & 33 & 15.6061 & 3.69915 & .64394 \\
& 2 & 77 & 16.7792 & 4.30001 & .49003 \\
\hline \multirow{2}{*}{$\mathrm{TD}$} & 1 & 33 & 9.2424 & 2.16550 & .37697 \\
& 2 & 77 & 11.0260 & 2.62064 & .29865 \\
\hline \multirow{2}{*}{$\mathrm{EF}$} & 1 & 33 & 9.8485 & 1.90593 & .33178 \\
& 2 & 77 & 10.6234 & 2.33981 & .26665 \\
\hline \multirow{2}{*}{$\mathrm{PE}$} & 1 & 33 & 12.5758 & 3.02107 & .52590 \\
& 2 & 77 & 15.2857 & 2.79500 & .31852 \\
\hline \multirow{2}{*}{$\mathrm{SK}$} & 1 & 33 & 12.2727 & 3.41204 & .59396 \\
& 2 & 77 & 15.4156 & 3.83320 & .43683 \\
\hline \multirow{2}{*}{$\mathrm{CB}$} & 1 & 33 & 9.7879 & 2.60717 & .45385 \\
\end{tabular}

To check whether these observed differences are statistically significant, independent samples $t$-tests were run. Table 5 presents the results of $t$-test run on identity components. As it can be seen, there are statistically significant differences between male and females in four components of identity as follows: TD $(t=-3.436, p$ $<.05), \operatorname{PE}(\mathrm{t}=-4.548, \mathrm{p}<.05)$, SK $(\mathrm{t}=-4.068, \mathrm{p}<.05)$, and CB $(\mathrm{t}=-2.952, \mathrm{p}<.05)$.

Table 5

Independent T-Test Displaying the Results of Gender-Differences in Identity

\begin{tabular}{llllll}
\hline & $\mathrm{t}$ & $\mathrm{df}$ & Sig. (2-tailed) & Mean Difference & Std. Error Difference \\
\hline $\mathrm{SE}$ & -1.365 & 108 & .175 & -1.17316 & .85953 \\
$\mathrm{TD}$ & -3.436 & 108 & .001 & -1.78355 & .51900 \\
$\mathrm{EF}$ & -1.678 & 108 & .096 & -.77489 & .46192 \\
$\mathrm{PE}$ & -4.548 & 108 & .000 & -2.70996 & .59586 \\
$\mathrm{SK}$ & -4.068 & 108 & .000 & -3.14286 & .77262 \\
$\mathrm{CB}$ & -2.952 & 108 & .004 & -1.51082 & .51186 \\
\hline
\end{tabular}

Another objective of the present research was to explore the role of teachers' educational level in their teacher identity. A one-way ANOVA was applied to compare the mean scores of the three groups of teachers on identity components. The first group comprised teachers who held a B.A. degree or were B.A. students; the teachers in the second group had an M.A. degree or were M.A. students, and the teachers in the third group were Ph.D. students. Table 6 depicts the means of each level as follows: 
The first group:

$\mathrm{SE}(\mathrm{M}=16.59, \mathrm{SD}=4.05), \mathrm{TD}(\mathrm{M}=11.18, \mathrm{SD}=2.26), \mathrm{EF}(\mathrm{M}=10.65, \mathrm{SD}=2.19), \mathrm{PE}(\mathrm{M}=15.18, \mathrm{SD}$ $=2.90)$, $\mathrm{SK}(\mathrm{M}=15.65, \mathrm{SD}=3.92)$, and $\mathrm{CB}(\mathrm{M}=11.13, \mathrm{SD}=2.51)$.

The second group:

$\mathrm{SE}(\mathrm{M}=16.02, \mathrm{SD}=4.10), \mathrm{TD}(\mathrm{M}=10.30, \mathrm{SD}=2.88), \mathrm{EF}(\mathrm{M}=9.95, \mathrm{SD}=2.27), \mathrm{PE}(\mathrm{M}=13.89, \mathrm{SD}=$ 3.09), $\mathrm{SK}(\mathrm{M}=14.02, \mathrm{SD}=3.76)$, and $\mathrm{CB}(\mathrm{M}=10.67, \mathrm{SD}=2.50)$.

The third group:

$\mathrm{SE}(\mathrm{M}=17.00, \mathrm{SD}=4.54), \mathrm{TD}(\mathrm{M}=9.40, \mathrm{SD}=2.34), \mathrm{EF}(\mathrm{M}=10.80, \mathrm{SD}=2.19), \mathrm{PE}(\mathrm{M}=14.25, \mathrm{SD}=$ 3.43), $\mathrm{SK}(\mathrm{M}=12.90, \mathrm{SD}=3.94)$, and $\mathrm{CB}(\mathrm{M}=10.60, \mathrm{SD}=2.77)$.

Table 6

Descriptive Statistics of Identity Across Educational Level

\begin{tabular}{|c|c|c|c|c|c|c|c|}
\hline & & $\mathrm{N}$ & Mean & Std. Deviation & Std. Error & Minimum & Maximum \\
\hline \multirow{4}{*}{ SE } & 1 & 44 & 16.5909 & 4.05955 & .61200 & 5.00 & 23.00 \\
\hline & 2 & 46 & 16.0217 & 4.10685 & .60552 & 9.00 & 24.00 \\
\hline & 3 & 20 & 17.0000 & 4.54220 & 1.01567 & 11.00 & 24.00 \\
\hline & Total & 110 & 16.4273 & 4.14742 & .39544 & 5.00 & 24.00 \\
\hline \multirow{4}{*}{ TD } & 1 & 44 & 11.1818 & 2.26472 & .34142 & 7.00 & 15.00 \\
\hline & 2 & 46 & 10.3043 & 2.88189 & .42491 & 4.00 & 15.00 \\
\hline & 3 & 20 & 9.4000 & 2.34857 & .52516 & 5.00 & 13.00 \\
\hline & Total & 110 & 10.4909 & 2.61522 & .24935 & 4.00 & 15.00 \\
\hline \multirow{4}{*}{$\mathrm{EF}$} & 1 & 44 & 10.6591 & 2.19876 & .33148 & 5.00 & 15.00 \\
\hline & 2 & 46 & 9.9565 & 2.27016 & .33472 & 5.00 & 15.00 \\
\hline & 3 & 20 & 10.8000 & 2.19089 & .48990 & 6.00 & 14.00 \\
\hline & Total & 110 & 10.3909 & 2.23851 & .21343 & 5.00 & 15.00 \\
\hline \multirow{4}{*}{ PE } & 1 & 44 & 15.1818 & 2.90367 & .43774 & 10.00 & 20.00 \\
\hline & 2 & 46 & 13.8913 & 3.09285 & .45602 & 8.00 & 20.00 \\
\hline & 3 & 20 & 14.2500 & 3.43166 & .76734 & 10.00 & 20.00 \\
\hline & Total & 110 & 14.4727 & 3.11171 & .29669 & 8.00 & 20.00 \\
\hline \multirow{4}{*}{ SK } & 1 & 44 & 15.6591 & 3.92928 & .59236 & 7.00 & 20.00 \\
\hline & 2 & 46 & 14.0217 & 3.76232 & .55472 & 7.00 & 20.00 \\
\hline & 3 & 20 & 12.9000 & 3.94568 & .88228 & 8.00 & 20.00 \\
\hline & Total & 110 & 14.4727 & 3.96940 & .37847 & 7.00 & 20.00 \\
\hline \multirow{4}{*}{$\mathrm{CB}$} & 1 & 44 & 11.1364 & 2.51129 & .37859 & 6.00 & 15.00 \\
\hline & 2 & 46 & 10.6739 & 2.50381 & .36917 & 4.00 & 15.00 \\
\hline & 3 & 20 & 10.6000 & 2.77963 & .62154 & 7.00 & 15.00 \\
\hline & Total & 110 & 10.8455 & 2.54568 & .24272 & 4.00 & 15.00 \\
\hline
\end{tabular}

To substantiate whether these observed differences are statistically significant, ANOVA was applied to the data. The results of ANOVA represented in Table 6 were examined. It was revealed that there are significant differences among the three groups regarding TD $(\mathrm{F}=3.55, \mathrm{p}<.05)$ and $\mathrm{SK}(\mathrm{F}=4.04, \mathrm{p}<.05)$. 
Table 7

The Results of ANOVA for Determining the Role of Educational Level in Identity

\begin{tabular}{|c|c|c|c|c|c|c|}
\hline & & Sum of Squares & $\mathrm{df}$ & Mean Square & $\mathrm{F}$ & Sig. \\
\hline & Between groups & 15.304 & 2 & 7.652 & .440 & .645 \\
\hline \multirow[t]{3}{*}{ SE } & Within groups & 1859.615 & 107 & 17.380 & & \\
\hline & Total & 1874.918 & 109 & & & \\
\hline & Between groups & 46.406 & 2 & 23.203 & 3.551 & .032 \\
\hline \multirow[t]{3}{*}{ TD } & Within groups & 699.085 & 107 & 6.534 & & \\
\hline & Total & 745.491 & 109 & & & \\
\hline & Between groups & 15.192 & 2 & 7.596 & 1.531 & .221 \\
\hline \multirow[t]{3}{*}{$\mathrm{EF}$} & Within groups & 530.999 & 107 & 4.963 & & \\
\hline & Total & 546.191 & 109 & & & \\
\hline & Between groups & 38.666 & 2 & 19.333 & 2.035 & .136 \\
\hline \multirow[t]{3}{*}{ PE } & Within groups & 1016.752 & 107 & 9.502 & & \\
\hline & Total & 1055.418 & 109 & & & \\
\hline & Between groups & 120.754 & 2 & 60.377 & 4.046 & .020 \\
\hline \multirow[t]{3}{*}{ SK } & Within groups & 1596.665 & 107 & 14.922 & & \\
\hline & Total & 1717.418 & 109 & & & \\
\hline & Between groups & 6.282 & 2 & 3.141 & .480 & .620 \\
\hline \multirow[t]{2}{*}{$\mathrm{CB}$} & Within groups & 700.091 & 107 & 6.543 & & \\
\hline & Total & 706.373 & 109 & & & \\
\hline
\end{tabular}

\section{Discussion}

As mentioned earlier, there has been a wide interest on teachers' identity in recent years and the role it plays in effective teaching. Recently, a number of researchers have worked on various dimensions of this issue (e.g., Masoumpanah \& Zarei, 2014; Beauchamp \& Thomas, 2009; Sachs, 2001; Kao \& Lin, 2015). In line with these studies, this paper investigated the profile of EFL teachers' professional identity.

The results demonstrated that SE had the highest frequency among the teachers of our sample. SE by definition is the teachers' commitment to and evaluation of their job. In this study most teachers taught English in informal situations where their job status is not guaranteed and they almost always want to do their duties as best as they can so that they can stay in their work place and continue teaching. The next component with the highest mean was SK which is defined as the teachers' subject knowledge and approaches for delivering curriculum. As mentioned before, in our study teachers taught in informal situations where they have to compete with others, and struggle to linger in their positions. One factor which is always of great concern for language institutes is the teacher's knowledge. Concerning the aforementioned definitions and explanations, it seems plausible that the most important components of teachers' professional identity in the context of our study are SE and SK.

The second aim of this paper was to examine the relationship among the components of teachers' professional identity. As the results indicated, the highest correlation was observed between SK (instructional skills and knowledge) and PE (pedagogy), followed by the relationship between TD (teachers' duties) and PE (pedagogy). PE is defined as the teachers' students' behavioral education and relationships with students. Aligning this characterization with the definitions of SK, it can be concluded that when the teachers have more knowledge about the subject and approaches for teaching the curriculum, they have more awareness about students' behavior and they have enhanced mutual relationship with students and can easily establish rapport. TD 
means the teachers' responsibilities toward students, curriculum content, and society. In this case, when the teachers are more responsible toward the students and curriculum, they can win their trust and establish friendly and humanistic relationship with their students.

The third aim of this paper was to examine the relationship between Iranian EFL teachers' professional identity latent concepts and their teaching experience. To do so, a Pearson product-moment correlation was applied to the data. The findings indicated that there are significant correlations between teachers' teaching experience and SE, teachers' teaching experience and TD, teachers' teaching experience and $\mathrm{EF}$, teachers' teaching experience and PE, teachers' teaching experience and SK and teachers' teaching experience and CB. In other words, teachers who are more experienced tend to have higher commitment to and evaluation of their job, responsibilities toward students, curriculum content, and society, perceptions of social interactions and school policy, knowledge about students' behavioral education and relationships with students, subject knowledge and approaches for delivering curriculum, and devotion of additional efforts in their work and profession.

The fourth goal of this study is to investigate gender-differences in each identity component, for this purpose, independent samples $t$-tests were run. The results demonstrated that there are statistically significant differences between male and females in four components of identity TD, PE, SK, and CB.

The fifth purpose of this research was to examine the role of Iranian EFL teachers' professional identity in their educational level. A one-way ANOVA was applied to compare the mean scores of the three groups of teachers (the teachers in the first group held a B.A. degree or were B.A. students; the in the second group had an M.A. degree or were M.A. students, and the teachers in the third group were Ph.D. students) on identity components. The results showed that there are significant differences among the three educational groups regarding and SK.

\section{Conclusion and Implication}

Considering the role of teachers' professional identity in teachers' success in teaching and making good relationship with students, it was of great importance to examine what could affect this construct. According to our finding, it can be concluded that in the Iranian EFL institutes, there has been a tendency towards encouraging teachers to improve their knowledge, teaching strategies, pedagogy, and citizenship behavior which are some of the components of teachers' professional identity. In this paper, we sought to examine the role of teaching experience, teachers' gender and educational level in teachers' professional identity to present a more vivid view on the extent to which these variables are decisive and what teachers can do to improve their professional identity.

A few suggestions can be made regarding future studies. The present study was conducted only among teachers who taught English as a foreign language. Future studies can include teachers teaching other disciplines to pave the way for the cross comparison of the results. The identity was assessed through questionnaire. Further studies are recommended to employ qualitative approaches. These studies should use case studies, observations, and interviews to provide profound insight about the relationship. Administering the questionnaires to a larger size of sample would enhance the validity and generalizability of results. Because the results of this study were achieved through administering the instrument among teachers with a similar L1, which might have a large effect on their work motivation, it would be useful for future studies to examine the study across teachers who have different L1s. 


\section{References}

Abednia, A. (2012). Teachers' professional identity: Contributions of a critical EFL teacher education course in Iran. Teaching and Teacher Education, 28, 706-717.

Barrett, M. A. (2008). Capturing the difference: Primary school teacher identity in Tanzania. International Journal of Educational Development, 28(5), 496-507.

Beauchamp, C., \& Thomas, L. (2009). Understanding teacher identity: An overview of issues in the literature and implications for teacher education. Cambridge Journal of Education, 39(2), 175-189.

Beijaard, D., Meije, P., \& Verloop, N. (2004). Reconsidering research on teachers' professional identity. Teaching and Teacher Education, 20(2), 107-128.

Beijaard, D., Verloop, N., \& Vermunt, J. D. (2004). Teachers' perceptions of professional identity: An exploratory study from a personal knowledge perspective. Teaching and Teacher Education, 16(2), 749-764.

Carr, D. (2000). Professionalism and ethics in education. London: Routledge.

Crigger, N., \& Godfrey, N. (2014). From the inside out: A new approach to teaching professional identity formation and professional ethics. Journal of Professional Nursing, 30(5), 376-382.

Enyedy, N., Goldberg, J., \& Welsh, K. M. (2006). Complex dilemmas of identity and practice. Science Education, 90(1), 68-93.

Freeman, D. (1996). Redefining the relationship between research and what teachers know. In K. M. Bailey and D. Nunan (Eds.), Voices from the language classroom (pp. 88-115). Cambridge: Cambridge University Press.

Freeman, D., \& Johnson, K. E. (1998). Reconceptualizing the knowledge-base of language teacher education. TESOL Quarterly, 32(3), 397-417.

Friesen, M. D., \& Besley, S. C. (2013). Teacher identity development in the first year of teacher education: A developmental and social psychological perspective. Teaching and Teacher Education, 36, 23-32.

Grant, C., \& Zeichner, K. (1984). On becoming a reflective teacher. In C. A. Grant (Ed.), Preparing for receptive teaching (pp. 1-19). Newton, MA: Allyn and Bacon.

Griffiths, V. (2000). The reflective dimension in teacher education. International Journal of Educational Research, 33(5), 539-555.

Hamilton, S. E. (2013). Exploring professional identity: The perceptions of chartered accountant students. The British Accounting Review, 45, 37-49.

Ivanic, R. (1997). Writing and identity: The discoursal construction of identity in academic writing. Philadelphia: John Benjamin's Publishing Co..

Kao, Y., \& Lin, S. (2015). Constructing a structural model of teachers' professional identity. Asian Journal of Management Sciences \& Education, 4(1), 69-81.

Kerby, A. (1991). Narrative and the self. Bloomington: Indiana University Press.

Komba, W. L., Anangisye, W. L., \& Katabaro, J. K. (2013). The development of teacher professional identity at the University of Dar es Salaam: Perceptions and influencing factors. CICE Hiroshima University. Journal of International Cooperation in Education, 15(3), 187-204.

Kumaravadivelu, B. (2003). Beyond methods: Macrostrategies for language teaching. New Haven and London: Yale University Press.

Lasky, S. (2005). A sociocultural approach to understanding teacher identity, agency and professional vulnerability in a context of secondary school reform. Teaching and Teacher Education, 21(8), 899-916.

Lauriala, A., \& Kukkonen, M. (2005). Teacher and student identities as situated cognitions. In P. Denicolo and M. Kompf (Eds.), Connecting policy and practice: Challenges for teaching and learning in schools and universities (pp. 199-208). Oxford: Routledge.

Loughran, J. (2006). Developing a pedagogy of teacher education. Understanding teaching and learning about teaching. New York: Routledge.

Luehmann, A. L. (2007). Identity development as a lens to science teacher preparation. Science Education, 91(5), 822-839.

Masoumpanah, Z., \& Zarei, G. R. (2014). EIL, Iranian teachers' professional identity and perception of professional competence. Procedia - Social and Behavioral Sciences, 98, 1100-1109.

Nguyen, H. T. (2008). Conceptions of teaching by five Vietnamese American preservice teachers. Journal of Language, Identity \& Education, 7(2), 113-136.

Pinar, W. (2012). What is curriculum theory? (2nd ed.). New York: Routledge. 
Rus, C. L., Tomşa, A. R., Rebega, O. L., \& Apostol, L. (2013). Teachers' professional identity: A content analysis. Procedia Social and Behavioral Sciences, 78, 315-319.

Sachs, J. (2001). Teacher professional identity: Competing discourses, competing outcomes, Journal of Education Policy, 16(2), 149-161.

Sachs, J. (2005). Teacher education and the development of professional identity: Learning to be a teacher. In P. Denicolo and M. Kompf (Eds.), Connecting policy and practice: Challenges for teaching and learning in schools and universities (pp. 5-21). Oxford: Routledge.

Sfard, A., \& Prusak, A. (2005). Identity that makes a difference: Substantial learning as closing the gap between actual and designated identities. In H. L. Chick and J. L. Vincent (Eds.), Proceedings of the Twenty-Ninth Meeting of the International Group for the Psychology of Mathematics Education (1) (pp. 37-52), Department of Science and Mathematics Education, University of Melbourne, Victoria, Australia.

Singh, G., \& Richards, J. C. (2006). Teaching and learning in the language teacher education course room: A critical sociocultural perspective. RELC Journal, 37(2), 149-175.

Thomson, M. M., \& Palermo, C. (2014). Preservice teachers' understanding of their professional goals: Case studies from three different typologies. Teaching and Teacher Education, 44, 56-68.

Tsui, A. M. (2007). Complexities of identity formation: a narrative inquiry of an EFL teacher. TESOL Quarterly, 41(4), 657-680.

Varghese, M., Morgan, B., Johnston, B., \& Johnson, K. A. (2005). Theorizing language teacher identity: Three perspectives and beyond. Journal of Language. Identity \& Education, 4(1), 21-44.

Wallace, M. (1995). Training foreign language teachers: A reflective approach. Cambridge: Cambridge University Press.

Wenger, R. (1998). Communities of practice: Learning, meaning and identity. Cambridge: Cambridge University Press.

Woods, D. (1996). Teacher cognition in language teaching: Beliefs, decision-making, and classroom practice. New York: Cambridge University Press. 